\title{
Güney Kore'nin Ekonomik Elitleri ve Siyasal Sistem İçerisindeki Konumları
}

\section{Economic Elites of South Korea and Positions Thereof in the Political System}

Özlem TEZER ${ }^{1}$

Article Info

Article History:

Date Submitted: 08.07.2019

Date Accepted: 23.08.2019

Jel Classification

N45, N95, O29, P41

Keywords:

South Korea,

Elite,

Chaebol,

Planning
Abstract

South Korea, along with its story of success in the field of economic development, has been the subject of a series of studies in the literature, dealing with the concept of chaebols, as distinctive actors in the said country's economy. This article aims to analyze the relationship between South Korea's political elites and economic elites in the historical perspective and to define the chaebols as actors both influencing the economic policies and affected by them. During the independence process in the aftermath of the end of Japanese invasion in South Korea, chaebols emerged as important players by the privatization of the previously nationalized enterprises. After the Korean War, economic growth was driven by the planned strategies and then the import substitution strategy was replaced by export-driven growth due to both internal and external factors. During this strategy transition process, the economic elites engaged in a relationship that could be considered first as a hierarchical and then a horizontal manner. The institutional legacies of this relationship have certain characteristics that reproduce itself and still shape South Korea's domestic and foreign policy.

\section{Özet}

Güney Kore, ekonomik kalkınma alanındaki başarısının yanı sıra kendine özgü bir ekonomi aktörü olan chaebollerle beraber literatürde birçok çalışmanın konusu oldu. Bu makale, Güney Kore'nin politik elitleri ile ekonomik elitleri arasındaki ilişkinin tarihsel süreç içerisinde analizini ve ekonomik elitler olan chaebolleri ekonomi politikalarını hem etkileyen hem de etkilenen bir aktör olarak tanımlamayı hedeflemektedir. Güney Kore'de Japon işgalinden sonraki bağımsızlık sürecinde devletleştirilen işletmelerin özelleştirilmesiyle chaeboller önemli oyuncular haline geldi. Kore Savaşı'nın ardından planlamacı stratejiyle ekonomik büyümenin yönlendirilmesi ve ardından ithal ikameci stratejinin yerini hem içsel hem dışsal faktörler nedeniyle ihracata dayalı büyümenin aldığı bu süreçte, ekonomik elitler politik

\footnotetext{
${ }^{1}$ Doktora Öğrencisi, Ankara Üniversitesi Sosyal Bilimler Enstitüsü, Siyaset Bilimi Bölümü, tezerozlemm@gmail.com , arlemcans@gmail.com
} 
elitlerle önce hiyerarşik sonra da yatay kabul edilebilecek bir ilişki içerisinde yer aldılar. Bu ilişkinin kurumsal mirasları kendini yeniden üreten ve bugün bile Güney Kore'nin iç ve dış siyasetine yön veren bazı özellikler taşımaktadır.

\section{Giriş}

Güney Kore², "Han Nehri mucizesi” olarak adlandırılan, 1960 - 1980 döneminde hızla büyüyen ekonomisi ve bu ekonominin itici gücü olarak kabul edilen "planlama" nedeniyle literatürde birçok çalışmaya konu edilmiştir. Bu çalışmalarda bir başka öne çıkan husus ise, şöhreti ülke sınırlarını aşan konglomerat ${ }^{3}$ işletmeleri olan chaebollerin ekonomi içerisindeki rollerini anlamaktır. Planlamaya dayalı kalkınma yöntemini örnek alan, dünya markası haline gelen chaebolleri taklit etmeye çalışan birçok ülke de olmuştur.

Ekonomik sistem, organik olarak birbiriyle ilişkili bileşenlerden oluşan bir sistem olarak tanımlanabilir. Politik sistemi de bir başka bileşenler ve ilişkiler sistemi olarak tanımlamak mümkündür. Ancak ekonomik sistemin bileşenleri, politik sistemin diğer bileşenleriyle ayrılmaz bir şekilde bağlanmıştır. Chaeboller de Güney Kore'nin kendine özgü politik sistemi içerisinde siyasetten hem etkilenen hem de onu etkileyen bir bileşen olarak değerlendirilmelidirler.

$\mathrm{Bu}$ çalışmanın hedefi, Güney Kore'nin ekonomik seçkinleri olan chaebolleri, siyasi sistem ile olan ilişkileri içerisinde tanımlamak ve tarihsel süreçte karşılıklı etkileşimlerini analiz edebilmektir. Ancak bu çalışmada, Kore'de siyasetin finansmanı, ülkedeki seçim sistemi, sivil toplumun etkinliği veya Kuzey-Güney Kore ihtilafları gibi bazı faktörler kapsam sınırlaması bakımından dışarıda bırakılmıştır.

Öncelikle Kore'nin siyasi tarihi içerisinde chaebollerin meydana çıkması kalkınma programları ile yaşanan dönüşümleri, politik elitlerle olan ilişkilerinin şekillenmesi incelenecek, daha sonra Kore'ye özgü politik kültürün bu ilişkinin biçimlenmesindeki rolüne değinilecektir.

\footnotetext{
${ }^{2}$ Bu çalışmada "Kore" ifadesi, aksi belirtilmedikçe "Güney Kore" olarak da bilinen "Kore Cumhuriyeti” ni anlatmak için kullanılmıştır.

${ }^{3}$ Konglomerat: 1960 'lardan sonra literatürde duyulmaya başlayan bir terimdir, birçok farklı alanda faaliyet gösteren hukuken farklı ilişkiler içerisinde olan işletmenin tek bir isim altında toplanmış halidir. Kore'de en bilinen konglomeratlar Samsung, Hyundai, Daewoo gibi büyük ticari yapılanmalardır.
} 


\section{Kore Siyasi Tarihi ve Chaeboller}

Güney Kore, 60'lı ve 70'li yıllarda, ekonomik büyümenin zirveye ulaştığı dönemde, chaeboller olarak bilinen ekonomik elitlerin ekonomi sahnesine çıkmasına tanık oldu. Geleceğe dair umut taşıyan belirli endüstriler için seçici ve tercihli destekleme politikası, bu ekonomik aktörlere önünde engel çıkarılmayan büyüme firsatları yarattı.

Bu dönemde, ülke siyasetinde demokratikleşmenin sağlanamadığı ve kesintiye uğradığ yıllar boyunca chaeboller, ülkedeki siyasi elitler ile yakın ilişkilerini sürdürdüler. chaebollerin büyümesinin ve değişmesinin incelenmesi, Güney Kore'de siyasi ve ekonomik güçler arasındaki tamamlayıcı ilişkiyi anlamak açısından son derece önemlidir.

\section{Chaebollerin Kökenleri ve Özellikleri}

Chaebol, farklı iş kollarıyla uğraşan ve tipik olarak birbirleriyle ilişkili bir veya iki aile grubu tarafından sahip olunan ve kontrol edilen çeşitli şirket girişimlerinden oluşan bir finansal klik olarak tanımlanmıştır. (Steers, Shin, \& Ungson, 1989 ve Hasegawa, 2011)

$\mathrm{Bu}$ yapının altı ana özelliği vardır:

1) Aile kontrol ve yönetimi,

2) Ataerkil liderlik,

3) Merkezi planlama ve koordinasyon,

4) Girişimcilik odaklılık,

5) Yakın şirket-hükümet ilişkileri ve

6) İşe alım politikalarındaki güçlü okul bağları.

$\mathrm{Bu}$ özelliklerine bakılarak chaebol, küçük ve orta ölçekli işletmelerden farklılaşan, ayrıcalıklı iş aristokratlarına benzemektedir. Bu bağlamda, chaebol, ataerkil bir aile işletmesi gibi çalışan Alman konzern'e oldukça benzer. Ancak chaebollerin kurumsal mirası, Japonya'daki zaibatsu' ${ }^{4}$ 'lardan gelmektedir.

\footnotetext{
${ }^{4}$ 19.yy'da ortaya çıkmış bir terimdir. Japonya'da geniş aileler tarafından yönetilen, sektörel olarak monopol gücünü elinde bulunduran işletmelerdir. Bu işletmeler ekonomik olarak gruba bağlı şirketler, bankalar ve sanayi kuruluşlarının da yönetimini kontrol etmektedirler.
} 
Kore cheabollerinin kökleri, Kore Savaşı'ndan sonra ekonomik kalkınma odaklı devlet teşviklerinin verilmesine kadar izlenebilir. Savaş sonrasında yüksek katma değerli olduğu düşünülen endüstriler için seçici desteğin, ulusal kalkınmanın ivme kazanması ve modernleşmeyi yönlendirmesine yardım etmesi planlanmaktaydı. Ekonomik kalkınmanın egemenliği, chaebollerin kendi yollarının üzerinde duran her şeyi tüketen devasa omnivorlara dönüşmeleri için verimli bir zemin sağlamıştır.

Sik sık yaşanan siyasi dönüşümlerle, chaebollerin gelişmesi, farklı ancak sürekli değişen bir profil göstermektedir. Bu büyüme süreci beş döneme ayrılabilir:

1) Yeniden Yapılanma Dönemi (1945 - 49)

2) Savaş ve Ekonomik Kriz (1950 - 1960)

3) Ekonomik Gelişme ve İhracata Dayalı Büyüme (1961 - 1971)

4) İhracata Yönelik Politikaların Kurumsallaşması ve Seçici Endüstri Destekleri $(1972$ - 1986)

5) Chaeboller ile Değişen İlişkiler (1986 - Halen)

\subsection{Yeniden Yapılanma Dönemi (1945 -49)}

Japon sömürgeciliği döneminde, Korelileri baskı altında tutmayı amaçlayan sömürge politikası nedeniyle, ülkenin ekonomisinin kendi kendine yeten seviyeye ulaşmasını engelleyecek düzeyde özel sermaye eksikliği vardı. Koreli milli sermayenin oluşumu, Japon işgalcilerin geri çekilmesi ve mülkiyetlerine el konulmasıyla başladı. Geri-alınan mülkler ve işletmeler ekonominin hemen her alanındaydı: fabrikalar, madenler, gemiler vs. Bu mülkiyetlerin toplam değeri, ülkedeki toplam mülkiyetin yaklaşı \% $\% 70-80$ 'i kadard 1 (Grajdanzev, 1944).

1949'da, Geri Alınan Mülkiyetin Tasarrufu Kanunu, Ulusal Meclis tarafından kabul edildi, bu kanuna göre işgalcilere ait devlet tarafından el konulan mallar, özellikīe de işletmeler, Mayıs 1958'e kadar elden çıkarılacaktı. Mülkiyetin elden çıkarılması sürecinde, büyük Japon işletmeleri Korelilere verildi. Bu şirketlerin yanı sıra ülkede, 1940'ların sonlarında ve 1950'lerin başında kurulan bazı firmaların da, 1948'den 1960'a kadar süren Syngman Rhee'nin Birinci 
Cumhuriyeti ile yakın ilişkileri vardı. Bu firmaların birçoğunun bazı rüşvet ve diğer ödemeler karşılığında devletten özel imtiyazlar kazandığı iddia edildi (Savada \& Shaw, 1992).

\subsection{Savaş ve Ekonomik Kriz (1950-61)}

25 Haziran 1950'de Kore Savaşı başladı. Savaş, Kore'ye büyük zarar verdi; yoksulluk ve açlık ülkeyi sardı ve ülkenin parasal ve finansal sistemleri durma noktasına geldi. Kore'nin sanayi tesislerinin çoğu, Kore Savaşı sırasında tahrip olmuş veya yıkılmıştı. Kuzey Kore'nin işgalini takip eden ilk üç ayda, Seul, Kyunggi ve Kangwon eyaleti bölgelerinde bulunan sanayi kompleksleri ağır hasar gördü (Lee, 2001).

Savaş, Kore'nin makro-ekonomisini de büyük ölçüde etkiledi. Banka tasarruflarında büyük çalışmalar yapıldı ve askeri harcamaların finanse edilmesine yardımcı olmak için dolaşımdaki para miktarı artırıldı. Enflasyon, nakliye ve lojistik güçlükler, üretim hatlarının tahrip olması, mal ve hizmetlerin dağıtımındaki duraksamalar ve üretim ve dolaşımdaki mal arzındaki keskin düşüşler nedeniyle artmıştır. Özellikle, yiyecek ve giysi gibi tüketim ürünlerinin fiyatları hızla yükseldi. (Savada \& Shaw, 1992) Savaş sırasında ABD'den gelen fonlar, işgücü maliyetlerine ve tüketim malları alımlarına harcanarak mevcut makroekonomik koşulları daha da kötüleştirdi.

$\mathrm{Bu}$ yıkım ve enflasyon piyasada yeni bir talep yarattı. Şirketler bu yeni talebe göre üretimlerini şekillendirdi. Hükümetin yeniden yapılandırma politikaları ve bununla birlikte kalkınma fonları, savaştan çok ağır etkilenen endüstrinin restorasyonunu amaçlıyordu. Bu politika çizgisi yeni iş firsatları yarattı. Savaş sırasında ve sonrasında, “üç beyaz: pamuk, şeker, un” talebindeki keskin artış, chaebollerin hızlı büyümesinde temel teşkil etti.

Kore Savaşı sırasında, hükümet tarafindan diğer sektörlerle ilgili olarak askeri harcamalarda çarpıcı ve orantısız bir artış oldu. Hükümet, savaş ve bunun sonucunda ortaya çıkan rehabilitasyon programlarını finanse etmekle meşgul olduğu için, ekonomik büyümeyi desteklemede bir atalet meydana geldi. Ulusal düzeyde stratejik bir planlama yapılmadı ve ulusal ekonominin ölçeği, sermaye birikimi için çok küçük kaldı.

Askeri malzeme talebini karşılamaya yönelik rekabetçi ortam piyasadaki karşılığını bulmak yerine, yoğun rant kollama faaliyetleriyle girişimcilerin hükümet yetkililerine erişimi sağlamak için yönelmesine yol açtı. Büyük işletmeler bu yarıştan muzaffer olarak çıktı. Benzer 
bir eğilim, banka kredileri için rekabetçi tekliflerde de görüldü; KOBİ'ler yerine chaeboller tercih edildi. Banka kredileri üzerinde tekelci bir konuma sahip olmaları hem reel hem finansal ekonomide bankacılık, imalat, ticaret ve diğer sektörleri kapsayan bu şirketlerin Alman konzernlerine benzer bir şekilde büyümelerine yol açtı.

Devlet kurumları bankaların en büyük hissedarlarıydı ve kredi alıcıları hakkında karar verme sürecinde güçlü bir kaldıraç oranı kullanıyorlardı. Bu kaldıraç oranı küçük işletmelerin bu avantajlı kredilerden faydalanmasını imkansız hale getirmişti. Bu süre zarfında hükümet, chaebolleri daha büyük hissedar olmaları için teşvik ederek bankaları özelleştirmeye yönelik çabalar da sarf etmiştir.

1954'te, Liberal Demokrat Parti, kendi siyasi hedeflerine finansal kaynak yaratmay1 amaçlayan bir planı uygulamaya koydu, bankacılık sektörünün merkezinde chaebollerin olması düşünülüyordu. İlk satış 1956'da gerçekleşti, pazarlık usulü banka özelleştirmesi yapıldı. Samsung Group'un kurucusu, Lee Byung-chul ve Daehan Tekstil Şirketleri'nin kurucusu Seol Kyung-dong, bu özelleştirmelerde kazanan teklifleri verenlerden bazılarıydı. İncelendiğinde, bu pazarlık usulünün tam bir açık rekabetçi teklif ilkesinden çok daha düşük ödemelerle bir avuç şirket tarafından bankaların hisselerine sahip olunmasına yol açtığg da görülebilir. (Kim, Kim, \& Kim, 2000, s. 20)

Bununla birlikte, politik ve ekonomik elitler arasındaki bu yakın ve girift bağlar, Rhee Syngman hükümetinde yolsuzluğun giderek yaygınlaşmasına yol açtı. Sonunda yolsuzluk ve bir dizi seçim skandalı, 1960’ta 19 Nisan Devrimi adlı bir öğrenci hareketini tetikledi ve Cumhurbaşkanı Rhee'yi görevden ayrılmaya zorladı. Rhee'den sonra kurulan hükümet, sadece iki yıl sürdü. 1961'de askeri bir darbeye liderlik eden ve sonunda 1962'de devlet başkanlığına yükselen Park Chung Hee, yönetimi devralmış oldu.

\subsection{Ekonomik Gelişme ve İhracata Yönelik Büyüme (1961-71)}

1962 yılında ilk 5 Yıllık Ekonomik Kalkınma Planı yürürlüğe kondu. Kore Savaşı sonrası tarım ve tarım odaklı sektörlerin başat olduğu Kore ekonomisinde büyük bir dönüşüm hedeflenmekteydi.

Üç büyük ekonomik dönüşüm, planın geneline hakim oldu:

1) Tarım ekonomisinden sanayi ekonomisine geçiş,

2) Merkantilist faaliyetlerden sanayi üretimine geçiş, 
3) İç tüketim için üretimden ihracat için üretime geçiş (Kim, 1997, s. 82).

Tercihli kredi destekleri ve emlak yatırımlarını içeren kalkınma odaklı ekonomi politikaları, chaebollerin genişlemesine olumlu etki etti. Birkaç büyük şirkete tercihli olarak destek verilmesinin temel nedeni, zaten başarılı olması beklenen sektörlerde faaliyet gösteren bu şirketlere verilen desteklerle ulusal kalkınmanın da desteklenmesinin sağlanacağına yönelik inanç idi. Ülkenin ekonomi politikasının ekonomik büyüme ve ithal ikameci sanayileşme odaklı olması, devleti bu işletmeleri desteklemenin çeşitli yollarını aramaya teşvik eden bir iklim yaratılmasını sağladı.

1960’l1 y1llarda ülkede hedeflenen endüstriyel alanlarda faaliyet gösteren dokuz chaebol, tüm teşvik kredilerinin yüzde 40'ına sahip görünüyordu. (Kim, Kim, \& Kim, 2000) Ancak, yüksek enflasyon oranlarının faiz oranlarını geride bırakmasıyla beraber, gayrimenkul ve hisse senetlerine yapılan yatırımın reel sektöre yapılan yatırımlardan daha kârlı olacağına inanıldı. Banka kredilerinin reel sektör yatırımlarında kullanılmadığı taktirde caydırıcı olacak önlemlere karşı bağışıklığı olan büyük kredi kullanıcıları, banka kredilerini spekülatif alanlarda kullanmaktan çekinmediler.

Kore'deki ekonomik gelişme yabancı sermayeye çok şey borçluydu. Yerli sermayesi sınırlı olan bir ülke için, kalkınma aşamasında yabancı sermayeye dayanmak kaçınılmazdı. Yabancı sermaye, dış borçlar, yabancı yatırımlar ve orta ve kısa vadeli kredilerden oluşmaktadır. Kore'ye dış yardım, hem ticari hem de devlet kredisi biçiminde geldi. Devlet kredileri, ulusal kalkınma hedeflerine ulaşmak için kamu programlarını finanse etmeyi amaçlamıştır. Şirketlerin sermaye gereksinimlerini karşılamak için tasarlanmış ticari krediler, devlet kredilerinden daha yüksek faiz oranları getirmiştir. Dış kredilerin düşük faiz oranları oldukça cazip olunca dış borçlar, dış kredilerle ödenir hale geldi. Dünyada, 1970'lerde meydana gelen petrol krizi dış kredilerdeki faiz oranlarının yükselmesine neden oldu, ancak yine de cazip kalmaya devam etti. 1980'lerin sonlarından 1990'ların başlarına kadar dünya genelinde ekonomik krizlerin yaşanmasıyla yabancı sermaye akışı oldukça azaldı ve Korede 1997'de IMF Krizi olarak bilinen ekonomik kriz zamanına dek hemen hemen aynı seviyelerde kaldı.

Kamu iktisadi teşebbüsleri hem gelişmiş hem de gelişmekte olan ülkelerde ekonomik kalkınmanın ilerletilmesinde önemli bir rol oynadı. Varlık sebepleri, kimi zaman özel sermaye eksikliği ya da politik amaçlarla uyumlu iş sektörlerinin mevcudiyeti oldu. Liberalizasyon dalgasında kamu iktisadi teşebbüslerinin varlığı eleştirilere hedef oldu. 1968'den itibaren, Kore 
Hükümeti, devlet tarafindan işletilen şirketlerin özelleştirilmelerine yönelik bir politika izledi madencilikten ulaşıma her sektörde yer alan şirketlerin çoğu özelleştirildi ve bu özelleştirmelerin büyük kısmı da Hyundai, Daewoo gibi büyük chaebollerle birleşme şeklinde gerçekleşti. (Kim, Kim, \& Boyer, 1994, s. 159) Bu büyük şirketlerin özelleştirilmesi, chaebollerin daha da büyümesine neden oldu, siyasi patronaj konusunda chaeboller arasındaki rekabet de sertleşmiş oldu. Belirli chaebollere verilen bu tür ayrıcalıklar, politik elitler ve siyasi elitler arasındaki beslenme zinciri hakkında söylentilerin artmasına neden oldu.

İlk 5 Yıllık Ekonomik Kalkınma Planı tam manasıyla uygulanamadan değişikliğe uğramak zorunda kaldı. Planın değişikliği, Güney Kore'nin ekonomi politikasındaki bir dönüşümün parçası idi. Bu politikadaki en temel değişiklik ithal ikameci stratejiden ihracat odaklı büyüme stratejisine geçiş oldu. Politika değişikliğinin nedenleri arasında en önemlisi, yaşanmış olan sert devalüasyon idi. Devalüasyonla beraber rekabetçi bir döviz kuru gündeme geldi, doğrudan hedeflenmeyen bu devalüasyon karşısında politika yapıcıların önündeki en avantajlı seçenek, ihracat odaklı büyüme stratejisi oldu. İkinci önemli neden ise, 1963 'te ABD'den gelen yardımın kesilmesiydi. Kore Savaşı sonrasında ikiye bölünen ülkede doğal kaynaklar Kuzey Kore'nin kontrolünde kalmıştı, Güney Kore ekonomisinin doğru çalışması için doğal kaynakları ve ara malları ithal etme zorunluluğu, ihracata yönelik bir büyüme stratejisinin kaçınılmaz bir seçenek olduğu anlamına geliyordu. Üçüncüsü ise, Kore üretim sektörünün aşırı kapasite sorunu yaşaması idi. (Korea Development Institute, 2013). Bu çerçevede hükümet, 1964'te İlk 5 Yıllık Ekonomik Kalkınma Planını (1962-66) değiştirdi. Başlangıçta bir ithal ikameci politika çerçevesinde tasarlanan plan, ihracatı teşvik eden bir plana uyarlanmalıydı. Kore hükümeti, çeşitli ihracatı teşvik mekanizmalarını uygulamaya başladı. Ancak bu mekanizmalar başlangıçta parça parça uygulanan politikalar halini aldı. Aynı yıl, hükümet tüm geçmiş ihracat teşvik mekanizmalarını kapsamlı bir çerçevede bir araya getiren Kapsamlı İhracat Promosyon Programını yürürlüğe koydu. Bu yeni program tüm teşvik mekanizmalarını bir araya getirmekle yetinmedi, bir adım daha ileri gitti ve ihracata yönelik sanayileri teşvik etmek için başka bir dizi uygulamaları da hayata geçirdi. Bu haliyle ülkedeki ekonomi politikası artık ticaret politikasından ziyade bir sanayi politikasıydı. (Yoo, 2008) Bu değişiklikleri takiben ülkenin ihracatı hızla arttı. Başarısı birçok faktöre atfedilebilecek 7 yıllık bir süreçte ihracatta neredeyse on kat artış oldu. Bu tablonun arkasındaki en dikkate değer etken, chaebollerle politika yapıcıların çıkarlarının uyumu idi. Chaeboller için hükümetle tam bir iş birliği, daha fazla kâr anlamına geliyordu. 
İhracat performansı devlet başkanı tarafından yakından takip edilmekteydi. 1965 yılında Başkan Park, İhracatın Teşviki ve Geliştirilmesi için Aylık Genişletilmiş Toplantılara bizzat başkanlık etmeye başladı. Bu toplantılara ekonomi ile ilgili bakanlıkların bakanları, Kore Merkez Bankası, KOTRA ${ }^{5}$, Kore Ticaret Odaları Birliği, Kore Ticaret Odası, ticari bankalar, önde gelen ihracat firmaları ve ticaret uzmanları katılıyordu. Toplantılarda ihracat performans1, Kapsamlı İhracat Teşvik Programının gelişimi ve cumhurbaşkanlığı direktiflerinin ne şekilde uygulandığı gündeme geliyordu. Ayrıca, ihracatın genişletilmesindeki, güçlükler tespit ediliyor, uygulanabilir çözümler aranıyor ve takibi için başkanlık yönergeleri çıkarılıyordu. (Yoo, 2008)

60'lı yıllarda Kore'nin başarılı bir ihracat politikası yürütebilmesinin dışsal faktörleri de önemlidir. Dünya ekonomisi hızla büyüyor ve Kore mallarına olan talep artıyordu. İki kutuplu dünyada devam eden Soğuk Savaş Kore'nin müttefiklerine ihracatını artırmasına yardımcı oldu. Kore, ayrıca 1964'te Vietnam Savaşı'na katıldı ve bu da yeni iş firsatlarına kapıyı açtı.

Dünya çapındaki petrol şokunun ardından Orta Doğu iş için çok cazip hale geldi. Koreli şirketlerin bölgedeki inşaat taleplerini karşılama konusundaki girişimleri, sınırsız hükümet desteği vaadiyle ilerledi. Kapalı kapılar ardında yapılan müzakereler kişisel ya da siyasi bağlantılar tarafindan yönlendirildi. Bu süreçte, hükümetin bu şirketlere güçlü desteği ile beraber diplomatik mahareti, Orta Doğu'da iş yapma yolundaki bariyerleri ortadan kaldırmak için elzemdi. Bu süreç, politik ve ekonomik elitler arasında yeni bir köprü oluşturdu.

\section{4 İhracata Yönelik Politikaların Kurumsallaşması ve Seçici Endüstri Destekleri (1972 - 1986)}

1970’lerde bir dizi gelişmeyle beraber Kore hükümeti ekonomik kalkınmada seçici endüstrileri daha yoğun ve aktif biçimde desteklemeye ve bu alanlara başka araçlarla doğrudan ve dolaylı müdahale etmeye başladı, bu durum iş dünyasının ve politikanın oyuncularını da etkiledi ve chaebollerle hükümet ilişkilerinde bir başka dönem başladı.

\subsection{1 Ăğı Sanayi ve Kimya Endüstrileri (ASK)}

1970’lerin başında Ağır Sanayi ve Kimya Endüstrileri Kore ekonomisinde hızla gündeme geldi. Bu gelişmeye bir dizi faktör neden olmuştu. Birincisi, 1969'da Başkan Nixon'ın

\footnotetext{
${ }^{5}$ KOTRA: Başlangıçta Kore İhracatı Teşvik Kurumu (Korea Trade Promotion Corporation), 1995'ten beri Kore Ihracatı Teşvik Ajansı olarak
} 
Nixon Doktrini'ni açıklamasıyla jeopolitik durumda yaşanan değişiklikti. Nixon, artık müttefiklerinin kendi askeri savunma harcamalarıyla ilgilenmelerinin beklendiğini ifade etmişti. Bu durumda Kuzey Kore'yi ciddi ve yakın bir tehdit olarak gören Güney Kore'nin savunma ile ilgili sanayilere ağırlık verme mecburiyeti gündeme gelmişti. İkincisi, Kore'de emek piyasasında talebin giderek artmasıyla reel ücretlerde yaşanan artıştı. Bu durumda ağır sanayi ve kimya endüstrileri gibi sermaye yoğun sektörler, tekstil ve spor ayakkabısı üretimi gibi emek yoğun sektörlerden daha parlak bir gelecek vaat ediyordu (Amsden, 1989). Üçüncüsü, Anayasa'yı askıya alan Başkan Park'ın, ekonomik büyümeyi hızlandırarak meşruiyeti kazanmayı amaçlamasıydı. Yushin Rejimi ${ }^{6}$ Başkan Park'ı siyasi muhalefete karşı korurken Ağır Sanayi ve Kimya Endüstrileri konusundaki politikaları da hızla ve kesintisiz uygulamaya koymasını sağladı. ASK endüstrilerine pozitif ayrımcılık, belirli bir endüstride aşırı konsantrasyonla o piyasadaki rekabet, doğal kaynakların verimli bir şekilde dağılmasını engelleyecek bir hal alabilirdi. Sonuçta, ilgili tüm girişimlerin toplu iflasına yol açan bir sürece girilmesi de mümkündü. Bu riski gören Hükümet, chaeboller arasında 'fonksiyonel uzmanlık' olarak bilinen bir uygulamayı hayata geçirdi. Destekleri otomobil, iletişim ve elektrik kabloları, ağır inşaat ekipmanları, jeneratörler, kazanlar ve hidrojen peroksit sektörlerine ayırdı.

Kore'de, iç piyasa rekabet eden işletmeler arasında paylaşılamayacak kadar küçüktü; yeni endüstriler, piyasanın oligopolist hâkimiyetine açıktı. Hükümet, bir teşebbüsün genişlemesi ya da finansal yardım alabilmesi üzerindeki onaylama kontrolünü elinde tuttu. $\mathrm{Bu}$ mekanizma, chaebol oluşumuna elverişli bir iklimi teşvik etmede önemli bir rol oynadı.

ASK endüstrilerindeki bu devlet-iş alemi birlikteliği, Kore'yi bir dizi önemli mirasla terk etti. Ülkenin endüstriyel yapısını önemli ölçüde değişti ve o değişim Kore ekonomisini bugüne dek şekillendirdi. 1971'den 1979'a kadar ASK endüstrilerinin toplam üretime oranı yüzde 39'dan yüzde 55'e yükselirken, GSMH'da ihracatın payı yüzde 16'dan yüzde 36'ya yükseldi (Chang, 2003). Endüstri 1980'lerin başında büyük sıkıntı çekse de, 1980'lerin ikinci yarısında, düşük uluslararası faiz oranları, düşük ham petrol fiyatları ve düşük kur değerleri ile beraber Üç Düşükler olarak adlandırılan dönemde rekabet gücü kazandı. Çelik, makine, gemi inşa, elektronik ve petrokimya, Kore ekonomisinin ayrılmaz bir parçası oldu.

\footnotetext{
${ }^{6}$ Başkan Park'ın 1972'de bir dizi değişiklikle Anayasa ve Meclisi askıya aldığı sistem Yushin sistemi olarak bilinir.
} 


\subsubsection{Yartiletken Endüstrisinde Ar-Ge Teşviki}

Elektronik endüstrisi resmi olarak 1970'lerde hedeflenecek stratejik öneme sahip endüstrilerden biri olarak ilan edilmiş olmasına rağmen, çelik ve kimya endüstrisinden daha az önemli olarak kabul edilmişti. Bazı kesimler tarafından teşvikinin gereksiz ve verimsiz olduğuna da inanılıyordu (Kim S. R., 1998).

Hükümetin 1980'lerin başlarında yarı iletken endüstrisine yönelik politikası 1lımlı olmaya devam etti; bu durum, 1980'de iktidarı ele geçiren Chun Doo-Hwan rejiminin politik duruşunu da kısmen yansıtmaktaydı. Artan bir enflasyon oranına sahip olan yeni hükümet, para arzını ve kamu harcamalarını sıkılaştırmak ve Ağır Sanayi ve Kimya Endüstrisine olan desteğini azaltmak zorunda kaldı. 1980'lerin başında tüm dünyada liberalleşme ve özelleştirme dalgası görülüyordu. Etkileri Kore'de de görüldü. Tekel Yönetmeliği ve Adil Ticaret Yasası'nın 1980'de Aralık'ta yürürlüğe girmesiyle hükümet, piyasa rekabetini destekleme niyetini ortaya koydu.

Yeni hükümet bu esnada yarı iletken endüstrisinin önemini fark etti ve hatta Beşinci Beş Yıllık Ekonomik Kalkınma Planında (1982-1986) desteklenmesi için kilit endüstri olarak seçti. Ancak, Ulusal Yatırım Fonu'ndan sağlanan mali destek asgari düzeyde tutuldu. Ancak 1983'te orijinal plan yenilendi ve Gumi Şehri bir silikon vadisi inşa etmek için üs olarak seçildi. Amaç 1986 yılına kadar $\operatorname{VLSI}^{7}$ yongaları geliştirmekti. Koreli chaeboller zaten VLSI çiplerini geliştirmeye doğru ilerliyordu ancak kullandıkları yöntemleri ve geldikleri aşamayı paylaşmamak için silikon vadisine katılmayı reddettiler. Chun Doo Hwan hükümeti, şirketleri zorlamamayı tercih etti. Koreli chaeboller arasında Samsung, çip üretmede geliştirmede başarılı olan ilk şirket oldu. Samsung ve diğer şirketler, diğer ülkelere ihracatta bazı zorluklar yaşadılar, ancak Japonya-ABD ticaret çatışmaları, Japonya'ya konan ambargolar ve güçlü Japon yeni sayesinde bu zorlukları aştılar. Hükümet Samsung, Hyundai ve Goldstar'ı mikroçip üretiminde bir konsorsiyum kurmaya zorladı, ancak tarafların bu yüksek katma değerli endüstride bilgi paylaşımını reddetmesiyle konsorsiyum sadece finansal bir ortaklık olarak kald1.

$\mathrm{Bu}$ süreçten okunması gereken en önemli sonuç, tarihsel süreç içerisinde devletin sanayi ile olan ilişkisinin hiyerarşik bir süreçten adeta yatay bir sürece doğru geçiş yapmasıdır. Bu,

\footnotetext{
${ }^{7}$ VLSI: Very Large Scale Integration, Çok Geniş Ölçekli Tümleşim Yongaları binlerce transistörün tek bir yonga üzerinde birleştirilmesi yoluyla Tümleşik Devrelerin oluşturulmasıdır.
} 
hükümetin inşaat ya da ASK endüstrilerini teşvik ettiği 1970'lerde rolü ve ticaret sektörü ile olan ilişkisi ile farklı bir yapıyı işaret etmektedir. Her ne kadar hükümet yarı-iletken endüstrisini desteklenecek kilit endüstri olarak ilan etmiş olsa da, chaeboller üzerinde baskı kurmamıştır. Başlangıçta, mali yardım minimaldir ve hatta chaebolleri devlet destekli bir konsorsiyuma katılmaya ikna edememişlerdir. 64K ve $256 \mathrm{~K}$ DRAM'lerin geliştirilmesindeki ilk başarılar, devlet desteği olmadan sağlanmıştır.

\subsection{Chaeboller ile değișen ilișki (1986 - Halen)}

Yirmi yıllık ihracat ve ASK endüstrisi destek politikalarıyla chaeboller, olağanüstü bir büyümeyi deneyimlemiş ve önemli bir ekonomik güç haline gelmişlerdi. Politik elitler ve ekonomik elitler arasındaki ilişki bu dönüşümle beraber politik elitlerin tehdit altında hissetmelerine neden olacak bir seviyeye gelmelerine neden oldu. Bu durum, hükümetin Aralık 1986'da Tekel Yönetmeliği ve Adil Ticaret Yasasını revize etmesine neden oldu ve doğrudan chaebolleri düzenlemek için bir dizi yeni hüküm getirdi. Böylece, 1986, devlet ve işletme arasındaki gelişen ilişkide önemli bir yıl oldu.

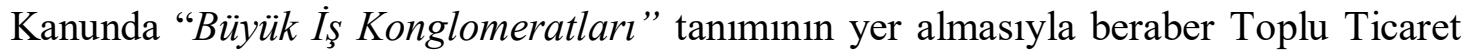
Komisyonu, her y1l aktif büyüklüğüne göre ilk 30 şirketi belirlemekle yetkili kılındı. Bu şirketlerde piramitleşen mülkiyet yapısı yasaklandı ve büyük şirketler gruplarının üye firmaları arasındaki karşılıklı payları da yasaklandı. Kardeş firmalara yapılan öz sermaye yatırımları net varlıkların yüzde 40'ı ile sınırlandırılmış ve finansal kuruluşların kardeş firmaları tarafından çıkarılmış hisselere oy kullanmaları yasaklanmıştır. Bunlar çok piyasa dostu düzenlemeler değildi.

Ancak chaeboller, 1980'lerin ikinci yarısında, son derece elverişli bir iş ortamı yaratan üç düşüklerin yardımıyla gelişmeye devam etti. Bu süre zarfında, chaeboller, Kore Menkul Kıymetler Borsası'ndaki piyasa kapitalizasyonlarını halka arz veya ikincil halka arz ile arttırmayı başardı. 1987 ve 1989 arasında, Kore Menkul Kıymetler Borsası'nda kote edilen firma sayıs1 389'dan 625'e yükseldi (Kim W. , 2011).

1990'da, Cumhurbaşkanı Roh Tae-Woo, chaebollere spekülatif gayrimenkul varlıklarını elden çıkarma ve varlık sebepleri olan üretim sektörlerine odaklanmaları konusunda 
bir emir yayınladı, bu sürecin en belirgin göstergesi olan emirle beraber, politik ve ekonomik elitler arasındaki gerilim başka bir düzeye taşınmış oldu.

Hyundai Grubu'nun kurucusu Chung Ju-Yung, 1992 seçimlerinde cumhurbaşkanlığına aday oldu. Bu adaylık, ekonomik elitlerin artık evlilik veya dolaylı ilişkilerle değil doğrudan politik karar alma süreçlerine katılım arzularını işaret ediyor ve Kore'de politik elitlerin geleneklerini alt üst ediyordu. Chung seçilmedi, ancak bu yeni atılımın yankısı devam etti.

Kore chaebollerinin gücü, 1997'de Asya krizinin ardından geçici olarak zayıfladı, çoğu iflas etti ve hayatta kalanlar da kendilerini yeniden yapılandırmak zorunda kaldılar. Güçlü politikacı olmak için geri dönerek bazen politikacıları ve bürokratları etkileyerek ekonomik politikaların yönünü kendi lehine şekillendirmek için hızla kendilerini yeniden adapte ettiler. Nitekim 2008 yılında eski Hyundai Group yöneticilerinden Lee Myung-Bak devlet başkanı olarak seçildi.

Bugün, Güney Kore chaebolleri dünya piyasasının marka değeri yüksek oyuncuları arasındadır (Tablo 1). Günümüzde, hükümetle chaeboller arasındaki ilişki eski hiyerarşik veya dikey ilişkiden çok yatay bir ilişki içerisindedir. Ancak bu ilişkinin zaman içinde hem dönüştüğü hem de dönüşüme zorladığı görülmektedir.

Tablo 1 En Büyük 10 Kore Şirketi ${ }^{8}$

\begin{tabular}{|l|l|l|l|l|l|l|}
\hline $\begin{array}{l}\text { Sıralama } \\
\text { (Kore/ } \\
\text { Global } \\
\text { Fortune500) }\end{array}$ & Şirket & Faaliyet Alanı & Satışlar & Kar & Aktifi & $\begin{array}{l}\text { Piyasa } \\
\text { Değeri }\end{array}$ \\
\hline $1 / 22$ & $\begin{array}{l}\text { Samsung } \\
\text { Electronics }\end{array}$ & Yarı İletken & 208,9 & 27,2 & 202,8 & 186,5 \\
\hline $2 / 87$ & Hyundai Motor & $\begin{array}{l}\text { Otomotiv } \\
\text { Üreticisi }\end{array}$ & 79,8 & 7,8 & 126,4 & 49,7 \\
\hline $3 / 236$ & $\underline{\text { Posco }}$ & Demir ve Çelik & 56,5 & 1,2 & 80 & 24,8 \\
\hline
\end{tabular}

\footnotetext{
${ }^{8}$ Rakamlar Milyar Dolar (B\$) cinsindendir.
} 


\begin{tabular}{|c|c|c|c|c|c|c|}
\hline $4 / 249$ & $\begin{array}{l}\text { Shinhan } \\
\text { Financial } \\
\text { Group }\end{array}$ & Yatırım & 19,6 & 1,7 & 295 & 21,1 \\
\hline $5 / 258$ & $\underline{\text { KIA Motors }}$ & $\begin{array}{l}\text { Otomotiv } \\
\text { Üreticisi }\end{array}$ & 43,5 & 3,5 & 34,3 & 22,8 \\
\hline $6 / 267$ & Hyundai Mobis & $\begin{array}{l}\text { Otomotiv } \\
\text { Parçaları }\end{array}$ & 31,2 & 3,1 & 32,6 & 28,7 \\
\hline $7 / 356$ & $\begin{array}{l}\text { Samsung Life } \\
\text { Insurance }\end{array}$ & Sigortacılık & 21,8 & 0,7 & 182.8 & 18 \\
\hline $8 / 370$ & $\begin{array}{l}\text { KB Financial } \\
\text { Group }\end{array}$ & Yatırım & 15,8 & 1,2 & 276,5 & 13,7 \\
\hline $9 / 439$ & $\underline{\text { SK Hynix }}$ & Yar1 İletken & 12,99 & 2,6 & 19,8 & 24,9 \\
\hline $10 / 457$ & $\begin{array}{l}\text { Hana Financial } \\
\text { Group }\end{array}$ & Bankacılık & 13 & 0,8 & 279,7 & 10,6 \\
\hline
\end{tabular}

Kaynak: Top 10 Korean Businesses in the World, (Kim S. , 2017)

Bu büyüklükteki şirketlerin Kore'de hükümet tarafından kontrol altına alınması oldukça zordur. Bugün bazı analistler politik elitlerin adeta hiyerarşik biçimde ekonomik elitlerin altında konumlandığını söylüyorlar. "1987 yılında politik olarak demokratikleştiği kabul edilen ülkenin ekonomik olarak demokratikleşmediği” (Ahn, 2003, s. 307) de ifade ediliyor. Güney Kore'de dönem dönem ekonomik elitlerle politik elitler arasındaki gerginlik çeşitli politika değişikliklerine yol açtı. 2016 yılından itibaren ülkede chaebollerin ve dönemin cumhurbaşkanının adının geçtiği bir yolsuzluk skandalı baş gösterdi (Griffiths, 2017). Skandal eski cumhurbaşkanı Park Geun-Hye de dahil olmak üzere birçok hükümet yetkilisinin ve Samsung Genel Müdürünün de aralarında bulunduğu bazı özel sektör çalışanlarının da yargılandığı ve art arda davaların açıldığı bir süreci başlattı. Bu sürecin tamamlanmasıyla 
ülkede chaeboller ve politik elitler arasındaki ilişkinin başka bir dönüşüm yaşayacağ 1 söylenebilir.

Güney Kore'de politik rejim, seçim sistemi ve ekonomik sisteminin farklılaşması, bu sistemin aktörleri olan ekonomik elitler ve politik elitleri dönüştürmekle beraber zaman zaman politik kültürün bazı miraslarının yeniden kendini ürettiğini söylemek mümkündür. Başlı başına bir başka çalışmanın konusu olabilecek bu kurumsal miraslar özellikle Kore politik kültüründe bölgeselciliğin, kan bağının, aile ilişkilerinin ve nihayetinde belli başlı okullardan mezun olmanın hemen her dönemde son derece önemli bir faktör olduğunu unutmamak gerekir. $\mathrm{Bu}$ nedenle Güney Kore'nin konglomeratları olan chaeboller bir yanıyla Kore ekonomisinin ve hatta dünya pazarının kendine has aktörü olmaya devam etmekte hem de geleneksel Güney Kore politik kültürüyle biçimlenerek politikadaki rollerini devam ettirmektedirler.

\subsection{SONUÇ ve DEĞERLENDİRME}

Kore'nin gelişmesindeki başarı, planlama modelini gelişmekte olan ülkelerin gündemine almasına neden olmuştur. Kore'nin planlama modeliyle beraber anılan chaeboller, bugün yalnızca Kore'de değil, dünya piyasasında da ünlü ve güçlü aktörlerdir. Bununla birlikte, bu başarı öyküsünün politik sistemler ve kurumlar açısından dikkate alınması gereken birçok yönü vardır. $\mathrm{Bu}$ nedenle, Kore'deki ekonomik elitlerle ile siyasi elitler arasındaki ilişkiyi tanımlamak, Kore'nin siyasi sistemi hakkında önemli bilgiler sağlayabilir.

Chaeboller Kore'nin ekonomik elitleridir ve hem Kore'nin siyasi sistemini etkilemekte hem de bu sistemden etkilenmektedirler. Ancak, onları siyasi kültürden, politik sistemden ve hatta siyasi tarihten ayırmak mümkün değildir. Bu makalede hem chaebol oluşumunu hem de politik elitlerle ve devletle olan ilişkilerini tarihsel bir perspektifle tartışmaya ve politik sistem ile ekonomi arasındaki ilişkiyi siyaset açısından aydınlatılmaya çalışıldı.

Güney Kore' de Japon işgalinin sona ermesiyle beraber birçok işletme kamulaştırıldı, bir taraftan da ekonomik açıdan artan ihtiyaçları karşılamaya yönelik devlet politikaları izlendi. Kore Savaşı ve sonrasında hem reel hem finansal sektördeki özelleştirmeyle beraber, ülkede chaebollerin ilk nüveleri de görüldü. Planlı kalkınma dönemiyle birleşen askeri iktidar, bu şirketlerin hiçbir engelle karşılaşmaksızın büyümelerine yardımcı oldu. Ortadoğu ile ilişkiler ise ekonomik ve siyasi elitlerin ilişkilerinin bir başka boyuta taşınmasını sağladı. İhracat odaklı büyüme politikalarının kurumsallaşması sonrasında devleşen chaeboller, politik elitlerin müdahalelerine kapalı, ekonomide hem reel hem finansal açıdan monopol hale geldiklerinden 
bir dizi anti-tröst yasasıyla karşı karşıya kaldılar ve bu nedenle siyasette doğrudan oyuncu olarak yer almak istediler.

1997 Asya Krizi ile beraber küçülmek zorunda kalan bu konglomeratlar, günümüzde dünya piyasasında etkin, marka değeri yüksek aktörlerdir. Dönem dönem siyasetle olan ilişkilerinde dönüşümler yaşanmış, bu ilişkilerin skandallaşması nedeniyle soruşturma ve yargılamalar başlamıştır. Bu sürecin sonunda ekonomik ve politik elitlerin ilişkilerinin farklı bir seviyeye geleceğini söylemek mümkündür.

Bu çalışmada, Kore'de siyasetin finansmanı, ülkedeki seçim sistemi, sivil toplumun etkinliği veya Kuzey-Güney Kore ihtilafları gibi bazı faktörler kapsam sınırlaması bakımından dışarıda bırakılan konuların chaebollere ve onların siyasi elitlere dolaylı ve doğrudan etkilerini inceleyen daha geniş bir çalışma, ekonomik ve siyasi elitlerin ilişkisine dair içgörüyü zenginleştirecektir. 
FSECON TEZER, Ö. (2019), "Güney Kore'nin Ekonomik Elitleri ve Siyasal Sistem İçerisindeki Konumlarl ", Fiscaoeconomia, Vol.3(3), 80-97.

\section{KAYNAKÇA}

\section{Çevrimiçi:}

Griffiths, J. (2017). CNN Cable News Network. Ocak 18, 2019 tarihinde CNN Web sitesi: https://edition.cnn.com/2016/11/02/asia/south-korea-president-scandalexplained/index.html adresinden alındı (Son Erişim Tarihi: 08.07.2019).

Kim, S. (2017). BTRAX. Ocak 18, 2019 tarihinde btrax web sitesi: https://blog.btrax.com/top10-korean-businesses-in-the-world-2015/ adresinden alındı (Son Erişim Tarihi: 08.07.2019).

\section{Çevrimdışı:}

Ahn, B.-M. (2003). Elites and Political Power in South Korea. UK: Edward Elgar.

Amsden, A. H. (1989). Asia's Next Giant: South Korea and Late Industrialization. New York: New York: Oxford University Press.

Chang, S.-J. (2003). Financial Crisis and Transformation of Korean Businness Groups. Cambridge: Cambridge University Press.

Grajdanzev, A. J. (1944). Korea in the Postwar World. Foreign Affairs, 22(3), 479 - 483.

Hasegawa, T. (2011). South Korean "Zaibatsu": An Analysis of Its Historical and Financial Characteristics. Y. Monden içinde, South Korean "Zaibatsu”: An Analysis of Its Historical and Financial Characteristics (s. 34). Tokyo: WSPC.

Kim, E. M. (1997). Big Business Strong State: Collusion snd Conflict in South Korean Development, 1960 - 1990. NewYork: State University of NewYork.

Kim, E. M., Kim, J.-K., \& Kim, J.-I. (2000). Restructuring of the chaebols and Financial Sestor in Korea: Progress and Assessment Since the Financial Crises. Kitakyushu: The International Centre for the Study of East Asian Development.

Kim, I.-C., Kim, M.-K., \& Boyer, W. W. (1994). Privatization of South Korea's Public Enterprises. The Journal of Developing Areas, 28(2), 157 - 166. 
Kim, S. R. (1998). The Korean System of Innovation end The Semiconductor Industry: A Governance Perspective. Industrial and Corporate Change, 7(2), 275 - 309.

Kim, W. (2011). Korea's Capital Market Promotion Policies: IPOs and Other Supplementary Policy Experiences. SSRN.

Korea Development Institute. (2013). The Korean Economy: Six Decades of Growth and Development. Gale Asia.

Lee, J. W. (2001). The Impact of the Korean War on The Korean Economy. International Journal of Korean Studies, Spring / Summer, 97 - 118.

Savada, A. M., \& Shaw, W. (1992). South Korea: A Country Study. Washington D.C.: Library of Congress Federal Research Division .

Steers, R. M., Shin, Y. K., \& Ungson, G. R. (1989). The chaebol: Korea's New Industrial Might. New York: Harper \& Row/Ballinger.

Yoo, J. (2008). How Korea's Rapid Export Expansion Began in the 1960's: The Role of Foreign Exchange Rate. Korea Development Institute. 